\title{
Motivations and Challenges on the Use of ICT for Teaching Special Needs Students
}

\author{
Indah Puspawati ${ }^{1, *}$ Rohmi Juharoh ${ }^{2}$ \\ ${ }^{1}$ Universitas Muhammadiyah Yogyakarta \\ ${ }^{2}$ Universitas Muhammadiyah Yogyakarta \\ *Email: indahpuspawati@umy.ac.id
}

\begin{abstract}
ICT in education is a powerful force for boosting the modernization of education. The use of ICT in education lends itself to more student-centered learning settings. ICT for education refers to the development of information and communications technology specifically for teaching and learning purposes, while the ICT in education involves adopting general components of information and communication technologies in the teaching and learning process. Eventually, the teacher's role in learning using ICT has provided many students' achievements, especially for hearing impaired students. Therefore, the researcher wanted to find the teachers' motivation in using ICT and their challenges. A qualitative research design was conducted to answer the problem. Three teachers who teach hearing impaired students contributed as the participants in this research. The data were gathered using the interview. This research showed that providing unlimited access to teaching media, students' interest, and students' achievements motivated teachers to use ICT in the classroom. Furthermore, limited facilities, teachers' skills, and distracted students became challenges that the teachers faced while using ICT.
\end{abstract}

Keywords: Technology, ICT, Teaching Hearing Impaired Students, Benefit in Teaching Students, Challenges in Teaching Hearing Impaired Students

\section{INTRODUCTION}

The use of Information and Communication Technology (ICT) tools in learning are inevitable. ICT has been reported to have positive effects on teaching and learning, such as providing new positive teaching and learning environment [1], and it also gives positive effects for both the students and the teachers. For students, the use of ICT tools may improve their motivation [2] [3] engagement [4], and learning outcomes [5] [6] [7]. Some studies also indicated that using ICT tools for learning enabled students to learn onthe-job training [8] and prepare them for future employment. For teachers, the use of ICT helps teachers created a fun teaching and learning atmosphere [4] [9] because ICT tools enabled them to find exciting teaching sources and media more comfortable [3]. Besides, in terms of language learning, ICT tools also enabled teachers to have easier access to authentic materials with enormous linguistic resources [10].

Students with disabilities can also experience the many positive effects of using ICT in the classroom. ICT may provide features and platforms that help students with their disabilities. For example, for deaf students, videos, or visual graphics from specific online platforms can help students learn. Research also reported benefits of using ICT for students with disabilities similar to those students without disabilities. A study by J. M. Cassady [11] reported that students with disabilities could learn independently using ICT. ICT could also improve those students' motivation in learning [12] [13]. ICT enhanced the improvement of learning outcomes [14] [15]. Furthermore, for students with disabilities, ICT could develop students' literacy and communication skills [15] [13].

In the Indonesian educational context, the importance of using ICT in teaching and learning has been emphasized by the Ministry of Education, and schools are encouraged to integrate ICT into their classroom. As stated in a regulation issued by the National Education Department no. 16 of 2007, regarding teachers' competencies, one of the competencies that teachers must have is the competence to use ICT in the teaching and learning process. The latest curriculum reformation implemented in 2016, the 2013 curriculum, highlighted the more critical use of ICT in the classroom. Besides, the regulation issued by the Indonesian Ministry of Education and Culture no. 37 of 2018 states that the 
ability to use ICT tools should also become the basic competence for all students starting from elementary schools to senior high schools. Thus, teachers should not only use ICT in teaching but also teach students using ICT in their daily life. Thus, the Indonesian government has also made some attempts to improve ICT use in the classrooms, such as providing schools with facilities and infrastructure for ICT use and training teachers to use ICT facilities for their teaching.

However, attempts should also be made to investigate whether the use of ICT in the classroom has run and is expected. Many factors influence the success of implementing ICT in the classroom, and the teacher is one of the determinant factors in the successful implementation of ICT. For example, teachers believe in the importance of ICT in their classrooms. Their ability to use ICT in their teaching greatly influenced their practice to implement ICT in their classroom [16]. Research by S. Zamir and M. Thomas [17] also revealed that teachers' use of ICT in classroom teaching was greatly influenced by their perception, attitude, and motivation regarding using ICT. Therefore, teachers need to have a positive perception, attitude, and motivation for better success in using ICT in their classroom teacher. Similarly, a study by M. G. C. Nueva [18] revealed that the teachers' perception of how comfortable the use of ICT in their classroom teaching was a significant factor that determines whether they use ICT in their teaching or not. A different study by I. Backfisch, A. Lachner, C. Hische, F. Loose, K. Scheiter [19] also revealed that teachers' motivational believes, especially their believes about the value of ICT for their teaching, had a more profound influence on the use of technology in their teaching compared to their professional knowledge and expertise.

Thus, it is crucial to investigate teachers' beliefs, attitudes, and motivation in using ICT in their classroom teaching before investigating the successful practices of integrating ICT in the teaching and learning process. Research has been done to investigate the influence of the teachers' beliefs, attitudes, and motivation toward implementing ICT in the teaching and learning process for students without disabilities. Although proven that ICT also positively affects students with disabilities, more studies are necessary to investigate teachers' for students with disabilities perceptions. Therefore, this study investigates the perception of teachers who teach students with disabilities in using ICT in their classroom teaching and will only focus on using ICT for students. Also, this research focuses on investigating teachers' motivation and challenges in using ICT for hearingimpaired students.

\section{LITERATURE REVIEW}

\subsection{ICT in Education}

As in many aspects of life, ICT has a significant influence in the education field. ICT has a significant and vital role in developing the teaching and learning process [20]. Besides, ICT has been reported to benefit both the teachers and students in the classroom. A. Meyer, D. H. Rose [21] state that integrating ICT and education serves a different classroom instruction, and it will benefit both teacher and students. A. Suryani [22] also adds that using ICT in teaching and learning enables both the students and teachers to access information in the classroom and outside the classroom. Moreover, [23] confirms that ICT in education will make students passively learn the teaching materials and be actively involved in their learning process. ICT is also reported to improve students' literacy because ICT devices may improve students' interest in learning [24]. Research also reported that ICT's use improved students' achievement in the teaching and learning process [25]. Thus, the use of ICT in education is encouraged to facilitate teaching and learning better.

\subsection{Hearing Impairment}

Hearing impairment or hearing loss is the complete inability to hear a sound. It has many causes and can occur at any age. People can suddenly suffer from hearing loss as a complication of a virus or lose hearing over time because of disease, nerve damage, or injury caused by noise. Hearing loss is the broad term related to varying points from hard-of-hearing to total deafness. The big challenge facing students with hearing impaired is communicating. Hearing-impaired students differ widely in their communication sciences. Hearing loss affects learning and teaching, thereby causing substantial difficulties in academic achievement. The deaf learners experience massive linguistic problems due to their inability to develop spoken language and understandable utterances [26]. Arizona's Department of Education's Parent Information Network notes that "Since children with hearing impairments are unable to receive some sounds accurately, they often cannot articulate words clearly."

Impaired hearing is split into several groups. As reported by C. Mathers, A. Smith, M. Concha [27], the ranges of no impaired to profoundly impaired hearing categories are introduced. T. Hernawati [28] also emphasizes that there are five types of hearing loss. They are: 1) Mild Loses, a loss of 20-30 dB hearing ability that is hard to hear weak talk; 2) Marginal Loses, a loss of 30$40 \mathrm{~dB}$ hearing capacity that can understand the conversation at a distance of one meter; 3) Moderate Loses, a loss of 40-60 dB hearing capacity that can understand a loud conversation at a distance of one meter; 4) Severe Loses, a lack of ability to hear 60-70 dB. Some types of hearing impaired can still hear a loud sound from close distances, such as a car horn; 5) Profound Losses, a hearing loss $75 \mathrm{~dB}$ and higher that can hear loud noises at a 1-inch gap. 


\subsection{ICT for Hearing Impaired Students}

Taking potential benefits and the challenges of using ICT is crucial for all the companies involved in supporting students with hearing impairments. ICT will provide a safe and comfortable atmosphere for students with hearing impairments. They may seem more in power, be familiar with the necessary functions, and have a lot of little need to interact with others, which may have positive and negative consequences. ICT will enable hearing disabled students become more confident in the workplace and improve their home skills [29].

For their learning process, special needs students, mainly hearing-impaired students, use ICT. The use of ICT even becomes something familiar to them. The use of ICT has been widespread in all education elements, including education for special needs students [30]. One study conducted by B. Baglama, M. Haksiz, H. Uzunboylu [13] revealed that ICTs increased students' motivation to learn with hearing impairment. The researchers also found that ICT could have positive effects on the literacy skills of hearing impaired students.

Regarding the types of ICT used for hearing impairment students G. B.Nkansah and T. Unwin [31] stated that word processor, internet, and games are the tools that teachers mostly used when teaching hearing impaired students. Furthermore, H. Lidström and H. Hemmingsson [32] suggested some tools that can be used such as soft and hardware for text-generating and speechgenerating to aids communication for students with hearing impairment. They [32] also suggested using computer with special multimedia application. In general P. Williams, H. R. Jamali and D. Nicholas [33] suggested four ICT tools that can be used for special needs students namely, the internet, virtual learning environments (VLE), augmentative and alternative communication (AAC), and adaptive devices for students who have difficulties using ICT devices.

Studies showed that the benefits of using ICT become the teachers' motivation in using ICT in teaching and learning process, the benefits of using ICT for hearing impaired students may include improving students' literacy and communication skills [13] [15] since computers and multimedia software can give visual feedback which makes it easier for the students to understand auditory input [32]. Besides, special software for auditory training may improve students' speech perception ability [32]. Other benefits may include improving students' motivation in learning [12] [13], improving learning outcomes [14] [15], and enabling students to learn independently [11].

Despite the benefits stated earlier, the use of ICT for teaching and learning also revealed some challenges. Among the challenges were the lack of ICT facilities available [12] [16] [31] [35]. The facilities may include the computers, the software, and the ICT course available for hearing impaired students. Another challenge for using ICT was the professionally trained personals that have knowledge of not only software application, but also hardware procedure to operate the ICT [31]. This was in line with other studies that stated that teachers still needed support when using ICT [16] [36], especially when dealing with technical problem when using ICT for teaching.

\section{METHODOLOGY}

The research was conducted on teachers of hearing impairment students in a school for students with special needs in Indonesia. This school is one of the best schools for special needs students in one of Indonesia's provinces. This school accommodates many students with special needs, including students with hearing impairments. Besides, despite their special needs students, the students have already got a lot of achievements. The students also won some competitions and both students and the teachers. Thus, it may be interesting to see how teachers in this school facilitate their students' learning. Third, this school also provides good facilities related to ICT for their teaching and learning process.

This research used a qualitative case study as the research method. This study focuses on three teachers who have at least a five-year of experience in teaching students with hearing impairment. One male teacher, Alfa (pseudonym), has been teaching in the school for 14 years; two female teachers, Ani and Bella (pseudonym), have been teaching for 6 and 7 years. The teachers were also reported to have used ICT in teaching their hearingimpaired students. The participants, then, were interviewed regarding their practice in using ICT. Each participant was given about 11 questions in the interview related to their motivation and challenges in using ICT to teach students. The data were analyzed in three steps: transcription, coding, and categorizing. For the first, the researchers transcribed the audio recording into the text. Then, each participant's important information related to motivation and challenges in using the ICT was transcribed. Lastly, common themes in the interview were categorized. These themes were then described in detail and reported as findings. The findings were reported related to participants' point of view, and every name used in the findings were all pseudonym.

\section{FINDINGS AND DISCUSSION}

In the interview, the participants were asked about the type of ICT that they often used in their teaching, their motivation to use the ICT tools, and their obstacles when using them. When the participants were asked about the teaching media they used in teaching, they claimed to have used various teaching media such as realia, including the objects found outside the classroom, sign language, and pictures. The teachers claimed using the realia to help explain a complex idea to the hearingimpaired students. For the ICT tools, the participants reported having also used ICT tools such as IT boards, LCD projectors, E-book, youtube ${ }^{\circledR}$ videos, and Whatsapp ${ }^{\circledR}$ application for teaching. From this 
interview, these participants implemented ICT in their teaching, and then, the interview continued to ask their motivation in using the ICT in their teaching. The participants described their motivation to use ICT from its effect on both the teachers and the students, and their answers were then presented below.

\subsection{The teacher's motivation in using ICT}

The first and most common answer to what motivated the teachers in using ICT in their teaching was that using ICT. The participants in this research claimed that ICT enabled them to prepare various engaging teaching media for their hearing-impaired students. All the participants agreed with that statement. For example, in the interview, Ani stated that teachers were much helped by ICT because it was easier to prepare engaging teaching media. She also added that because of the minimum efforts in preparing the teaching media. She claimed that it improved her motivation for teaching the students. Similarly, Bella claimed that ICT enabled her to explore and find teaching media she needed, such as pictures and videos, which she expressed as the most appropriate teaching media for hearing impaired students. She also stated that pictures and videos helped her teach the hearing-impaired students easier.

The results of this research are similar to the research conducted by M. Sari [3]. She reported that participants in her study also found it easier to find information and teaching media. Specifically, for hearing-impaired students, this research also revealed that using ICT allowed the hearing-impaired students equal access to learning sources [34]. As the participants in this research expressed that using ICT enabled them to access teaching materials, especially for hearing impaired students. It means that hearing-impaired students could also have an equal opportunity to learn as students without disabilities. Thus, this reason could be a motivation for teachers to use ICT in their teaching.

The second theme emerging from the teachers' motivation to use ICT in their teaching was that students were interested in using ICT in the classroom. All three participants stated that their students were always interested and curious when using ICT in the classroom. This interest, then, led to some benefits in the teaching and learning process. Alfa stated that because the students were interested in learning whenever he used ICT in the classroom. Students paid more attention to learning. He added that the use of ICT focused students' attention on learning. Ani explained that she had limited examples of expressing herself using sign language when she taught her students using sign language. However, when she used Youtube ${ }^{\circledR}$ videos, the videos provided many more examples of using sign language. Thus, she claimed that her students were more interested in learning when she used Youtube ${ }^{\circledR}$ videos. Furthermore, Bella stated that because her students always showed interest when she used ICT in her class. She claimed that her class became more exciting and fun.
Many studies reported that using ICT in the classroom improved the students' interest in learning. T. M. Sylviyanti and Y. Q. Yusuf [16] described that using ICT in their research context created an enjoyable learning atmosphere that eventually improved students' interest in learning. Similarly, Nordin et al. [12] also claimed that students in their research were interested in using ICT, especially the ICT tools that consisted of interesting graphic images because the hearing-impaired students depended on images or vision a lot in their daily life, including learning. Thus, the images provided by the ICT tools were a great help for the students. Furthermore, Baglama et al. [13] also revealed that ICT made the lesson more exciting and increased the students' learning motivation. Hence, ICT can improve hearing-impaired students' interest and motivation in learning because of its many exciting features.

Third, the positive effect on students' achievement on ICT usage became the participants' motivation to use ICT in their classroom. All three participants argued that the use of ICT had increased students' achievement in the classroom. Bella expressed that the students' grade improved when she started to use ICT in her class, as she said, "When I did not use ICT for my class, my students' scores were barely in the minimum achievement criteria (KKM) set in the curriculum, but after I used ICT, my students' scores were above the minimum achievement criteria." She added that the improvement might come from the fact that she could teach more effectively with ICT. Alfa also stated that ICT made his learning objectives achieved easily using ICT. He affirmed that "It is very efficient to use ICT, and because the students were interested and can focus more on the lesson when I use ICT, my learning objectives can be achieved faster compared to when I did not use ICT." Similarly, Ani stated:

"The use of ICT for my hearing-impaired students has made my lesson more efficient, for example, when teaching my students, I often need to use physical contact with them to get their attention, and it takes time. However, when using ICT, I can get their attention easily, through picture or pop-up message, and it take less time, so that I could focus more on the lesson. I can also see that the students' achievement has improved steadily."

The improvement in students' achievement has driven the teachers to keep using ICT in the classroom despite the lack of skills, facility, and supports from the schools and other stakeholders, which become challenges in using ICT in teaching and learning.

Similar research in using ICT for hearing-impaired students revealed similar findings. For example, research carried out by P. I. Egaga and S. A. Aderibigbe [14] discovered that there was a positive correlation between the use of ICT and hearing-impaired students' academic performance. The hearing-impaired students who were taught using ICT showed more excellent academic 
performance than those who were not taught using ICE [14]. Likewise, research by Baglama et al. [13] also revealed that the use of ICT in e-learning increased deaf students' academic achievement and literacy skills. Halim et al. [7] also reported that the students who were taught using ICT showed better learning performance than those who were not using ICT. This result showed how ICT could be an essential tool to improve hearingimpaired students.

\subsection{Challenges in Using ICT}

This research aims to find the challenges teachers faced when using ICT in teaching hearing-impaired students. The foremost problem that they shared was the inadequate facilities supporting the use of ICT in the classroom. All teachers in this research claimed that it became the biggest challenge for using ICT in teaching and learning. All participants expressed that even though the school policy encouraged ICT use in their teaching and learning activities, the school did not provide adequate facilities such as a computer, Wi-Fi connection, and supporting software. All participants in this study claimed that they did not have enough computers for every student, and often time, one computer should be used by two students in one lesson. Alfa even claimed that students had to take turns when using a computer with students from other classes. Bella even described that she had to use her laptop to ensure the students having enough computers. Ani also criticized that even though the school encouraged the teachers to use ICT in their class, they did not provide enough computers for students to learn using ICT. Apparently, besides the computer, the teachers also had to deal with a bad Wi-Fi connection. All three participants reported having problems with Wi-Fi connections that did not support internet-based media, and all the teachers suggested that the school at least could provide a good Wi-Fi connection to access the internet for supporting teaching and learning through internet-based media. Besides, the inadequate facilities available were also reported to not functioning very well. Alpha and Bella claimed that they often found that the software was in error, and it made the teaching and learning process using ICT interrupted. Ani also asserted that she often wasted too much time meeting to fix the computer or software problems, leaving her with little time for her actual lesson.

In ICT for educational purposes discussion, the inadequate or limited facilities seemed to be recurrent issues. Research by T. M. Sylviyanti and Y. Q. Yusuf [16] conducted in Aceh, Indonesia, also revealed similar challenges. The teachers reported that the facilities needed for using ICT were not adequate, so they recommended that the government support the needs. Francis et al. [5] also reported that in their research context, in India, the government urged the schools to use ICT in their learning, but the access to ICT was only available to the privileged students, while there were many less privileged students did not get access to the ICT. This challenge was even worse for those who have disabilities, such as hearing-impaired students. Nordin et al. [12] reported that although hearing-impaired students were interested in learning about using ICT, ICT classes were not offered to them because they did not have enough computers. In a slightly different context, I. Eligi and K. Mwantimwa [35] also reported that in their research context, ICT facilities were inadequate to satisfy the needs of the students with impairment, significantly visually impaired students. The insufficient facility's problem could be long-lasting and demotivate teachers and students to use it in the classroom.

The second challenge that the teachers in this study faced when using ICT in the classroom was teachers' and students' skills. Ani and Bella revealed that even though they embraced ICT in their class, they would like to improve their skills in using ICT. Bella claimed that "I need to upgrade my skills in using ICT, especially for teaching using ICT. I was not trained in using ICT for teaching, but because of the demand nowadays, I need to learn to use them. " Ani also claimed that:

"I am not very confident with my skills in using ICT in my teaching. Besides, I can see that students know when their teacher is not good in using ICT, so I guess I have to improve my skills in using ICT. I hope the schools give us training on how to use ICT in the classroom effectively."

Besides the teachers' skills, students' skills in using ICT equipment varied, causing problems. Alpha stated that some of his hearing-impaired students also had a mental impairment making them slow learners so that they usually had low ability in using a computer. He then explained that using ICT gave him extra work with those students because he had to teach the students the subject and teach them how to use a computer. With some students already having good computer skills, this ability gap caused some problems when teaching using ICT. Therefore, both teachers' and students' skills played essential roles in using ICT in the classroom.

The teachers' knowledge and skills in using ICT were challenges that were also mainly reported by research done to investigate the teachers' readiness in using ICT in the classroom. Some research [14] [17] recommended giving teachers training or workshops to improve teachers' confidence and competencies in integrating ICT into their teaching. These activities should also be done continuously to keep teachers' knowledge and skills updated [17]. Other studies [16] [36] reported that teachers needed adequate supports in using ICT in the classroom. The support included support when encountering technical problems when using ICT for teaching. However, the discussion about the students' skills in using ICT was rarely discussed. Thus, this research finding could complete the finding of the challenges of using ICT for hearing-impaired students.

The last challenge discussed by the participants in this study was that the use of ICT could be a distraction to the hearing-impaired students. When using ICT, teachers and 
students were mostly required to access the internet, and when students accessed the internet, teachers in this study reported that most of the students were more distracted in accessing other websites than website directed for the teaching materials. Bella stated that students were more interested in accessing websites like youtube $\AA$, playing games, or other websites when asked to use the internet for learning. Anni also shared that the students did not focus on her lesson when using ICT since they were busy doing something on the internet. However, Alfa believed that the student being distracted with the IT was only the beginning stage as he claimed that "[When using ICT, students] may be distracted at first, and they might be not paying attention to the teacher, but eventually when they did not understand the material, they would pay attention to the teachers."

The research by D. Rodriguez-Gomez, D. Castro, and J. Meneses [37] about the problematic use of ICT among young people reported that the problematic use of ICT often occurred in the learning context, where students used ICT for other purposes while they were in the learning activity. Thus, it is recommended that teachers should foster responsible use of ICT both in learning and personal context [34]. Besides, P. I. Egaga and S. A. Aderibigbe [14] emphasized that to gain the benefit of using ICT, students should pay close attention and not get distracted. Otherwise, the use of ICT would not be beneficial for students' learning.

\section{CONCLUSION}

In all aspects of this era, ICT always plays an essential role. ICT also becomes a prior issue for use in the field of education. During their teaching and learning cycle, ICT will benefit both teachers and students. The use of ICT for teaching and learning processes has impacts, particularly for teaching to students with hearing impairments. Investigating the teachers' motivation to use ICT for hearing impaired students revealed that their needs became the primary motivation. In this study, the teachers claimed that they used ICT to give them more exciting teaching media needed by their students. Their desire to make students' learning more enjoyable to eventually improve the students' learning achievement was the main drive to use ICT in their class. However, these teachers also needed supports in terms of facility and training to make their teaching using ICT in their teaching using ICT to be more fruitful for the hearingimpaired students. Thus, this research recommends that ICT for hearing-impaired students be intensified since it will benefit hearing-impaired students. Finally, both teachers and students need to prepare well in using ICT in the classroom.

\section{REFERENCES}

[1] S. Muchamad, Pengembangan teknologi informasi dan komunikasi [Development of information and communication technology], Jurnal Studi Pendidikan Islam, 2018, 128.
[2] Y.T. Lin, M. Jou, Integrating popular web applications in classroom learning environments and its effects on teaching, student learning motivation and performance, Turkish Online Journal of Educational Technology-TOJET, 2013, 12(2), 157-165.

[3] M. Sari, The use of web 2.0 tools for learning in EFL context: pre-service teachers' voice, Journal of Foreign Language Teaching and Learning, 2020, 4(2), 135-149, DOI: https://doi.org/10.18196/ftl.4243

[4] G. Wikan, T. Molster, Norwegian secondary school teachers and ICT, European Journal of Teacher Education, 2011,34(2), 209-218, DOI: https://doi.org/10.1080/02619768.2010.543671

[5] M. Francis, F. Xavier, S. M. Malgatti, Use of multimedia (ICT) as an educational tool in high school education-a study, Amity Journal of Media \& Communications Studies (AJMCS), 2017, 7(1).

[6] N. T. Herawati, The implementation of selfregulated learning model using ICT media toward the students achievement in introduction to accounting course, Journal of Accounting and Business Education, 2017, 2(1), 144-157, DOI: http://dx.doi.org/10.26675/jabe.v1i1.9755

[7] H. A. Halim, A. Krishnasami, Y. H. Aziz, N S. Sulaiman, A. Kamaluddin, Investigation on student accessing information for ICT-learning approaches, Global Business \& Management Research, 2018, 10(3).

[8] L. Hortovanyi, A. Ferincz, The impact of ICT on learning on-the-job, The Learning Organization, 2015, DOI: https://doi.org/10.1108/TLO-06-20140032

[9] M. Mahdum, H. Hadriana, M. Safriyanti, Exploring teacher perceptions and motivations to ICT use in learning activities in Indonesia, Journal of Information Technology Education, 2019, 18, DOI: $10.28945 / 4366$

[10] D. Ciptaningrum, The development of the survey of technology use, teaching, and technology-related learning experiences among pre-service English language teachers in Indonesia, Journal of Foreign Language Teaching and Learning, 2017 2(2), 11-26, DOI: https://doi.org/10.18196/ftl.2220

[11] J. M. Cassady, Teachers' attitudes toward the inclusion of students with autism and emotional behavioral disorder, Electronic Journal for Inclusive Education, 2011, 2(7), 5.

[12] N. Nordin, M. M. Yunus, R. Zaharudin, H. Salehi, M. H. M. Yasin, M. A. Embi, Identifying the 
challenges and barriers hearing-impaired learners face with using ICT education courses, Journal of Theoretical and Applied Information Technology, 2015, 78(3): 327-335.

[13] B. Baglama, M. Haksız, H. Uzunboylu, Technologies used in education of hearing impaired individuals, International Journal of Emerging Technologies in Learning, 2018.

[14] P. I. Egaga, S. A. Aderibigbe, Efficacy of information and communication technology in enhancing learning outcomes of students with hearing impairment in Ibadan, Journal of Education and Practice, 2015, 6(30), 202-205.

[15] F. Alotaibi, N. Almalki, Saudi teachers' perceptions of ICT implementation for student with autism spectrum disorder at mainstream schools, Journal of Education and Practice, 2016, 7(5), 116-124.

[16] T. M. Silviyanti, Y. Q. Yusuf, EFL teachers' perceptions on using ICT in their teaching: to use or to reject?, Teaching English with Technology, 2015, 15(4), 29-43.

[17] S. Zamir, M. Thomas, Effects of university teachers' perceptions, attitude and motivation on their readiness for the integration of ICT in classroom teaching, Journal of Education and Educational Development, 2019, 6(2), 308-326.

[18] M. G. C. Nueva, Filipino teachers' attitude towards technology--its determinants and association with technology integration practice, Asia-Pacific Social Science Review, 2019, 19(3).

[19] I, Backfisch, A. Lachner, C. Hische, F. Loose, K. Scheiter, Professional knowledge or motivation? Investigating the role of teachers' expertise on the quality of technology-enhanced lesson plans, Learning and Instruction, 2020, 66, DOI: https://doi.org/10.1016/j.learninstruc.2019.101300

[20] A. Maida, Special education teachers' perceptions and practices of technology integration for supporting students with multiple exceptionalities. a research paper submitted in conformity with the requirements for the degree of master of teaching department of curriculum, Teaching and Learning Ontario Institute for Studies in Education of the University of Toronto, 2015.

[21] A. Meyer, D. H. Rose, The Future is in the margins: The role of technology and disability in educational reform, 2005.

[22] A. Suryani, ICT in education: Its benefits, difficulties, and organizational development issues, Jurnal Sosial Humaniora, 2010, 3(1), 13-33,
DOI:

http://dx.doi.org/10.12962/j24433527.v3i1.651

[23] K. Moyle, Leadership and learning with ICT. Voices from the profession. Teaching Australia. Australia: Australian Institute for Teaching and School Leadership LTD, 2006.

[24] L. A. Adonis, Technology in schools, The British Journal of Administrative Management, 2006 1415.

[25] A. B. Youssef, M. Dahmani, The impact of ICT on student performance in higher education: Direct effects, indirect effects and organisational change, Monograph "The Economics of E-learning," 2013, 51 .

[26] O. Sacks, Seeing voices: A journey into the world of the deaf, Pan Macmillan, 2009.

[27] C. Mathers, A. Smith, M. Concha, Global burden of hearing loss in the year 2000. Global burden of Disease, 2000, 18(4), 1-30.

[28] T. Hernawati, Pengembangan kemampuan berbahasa dan berbicara anak tunarungu, Jurnal JASSI_anakku, 2007, 7(1), 101-110.

[29] L. Gammaitoni, D. Chiuchiú, M. Madami, G. Carlotti, Towards zero-power ICT, Nanotechnology, 2015, 26(22), 222001-, DOI: doi:10.1088/0957-4484/26/22/222001

[30] J. Gardner, Information technology in special education, CASC Special Needs Paper, 2018.

[31] A. S. Drigas, R-E. Ioannidou, Special education and ICTs, iJET, 2013, 8(2), 41 - 47, DOI: http://dx.doi.org/10.3991/ijet.v8i2.2514

[32] H. Lidström, H. Hemmingsson, Benefits of the use of ICT in school activities by students with motor, speech, visual, and hearing impairment: A literature review, Scandinavian Journal of Occupational Therapy, 2014, (21), 4, 251-266. DOI: http://dx.doi.org/10.3109/11038128.2014.880940.

[33] P. Williams, H. R. Jamali, D. Nicholas, Using ICT with people with special education needs: What the literature tells us, Aslib Proceedings: New Information Perspectives, 2006, 58 (4), pp. 330-345. DOI: $10.1108 / 00012530610687704$.

[34] A. S. Drigas, R-E. Ioannidou, Special education and ICTs, iJET, 2013, 8(2), 41 - 47, DOI: http://dx.doi.org/10.3991/ijet.v8i2.2514

[35] I. Eligi, K. Mwantimwa, ICT accessibility and usability to support learning of visually-impaired students in Tanzania, International Journal of Education and Development using Information and 
Communication Technology (IJEDICT), 2017, 13 (2): 87-102.

[36] A. M. Johnson, M. E. Jacovina, D. E. Russell, C. M. Soto, Challenges and solutions when using technologies in the classroom. In S. A. Crossley \& D. S. McNamara (Eds.) Adaptive educational technologies for literacy instruction (pp. 13-29). New York: Taylor \& Francis. Published with acknowledgment of federal support, 2016.

[37] D. Rodriguez-Gomez, D. Castro, J. Meneses, Problematic uses of ICT among young people in their personal and school life, Media Education Research Journal, 2018, 56 (25), 91 - 100, DOI: https://doi.org/10.3916/C56-2018-09 